\title{
RECENT OCCURRENCES OF OPAH, LAMPRIS GUTTATUS (ACTINOPTERYGII, LAMPRIFORMES, LAMPRIDAE), IN THE WESTERN MEDITERRANEAN SEA
}

\author{
Patrice FRANCOUR ${ }^{1 *}$, Jean-Michel COTTALORDA ${ }^{1}$, Maurice AUBERT ${ }^{2}$, Simone BAVA ${ }^{3}$, \\ Marine COLOMBEY ${ }^{4}$, Pierre GILLES ${ }^{5}$, Hichem KARA ${ }^{6}$, Patrick LELONG ${ }^{7}$, \\ Luisa MANGIALAJO ${ }^{1}$, Roger MINICONI ${ }^{8}$, and Jean-Pierre QUIGNARD ${ }^{9}$ \\ ${ }^{1}$ University of Nice-Sophia Antipolis, ECOMERS, France \\ ${ }^{2}$ International University of the Sea, Cagnes-sur-Mer, France \\ ${ }^{3}$ Marine Protected Area of Bergeggi Island, V. de Mari 28/D 17028, Bergeggi (SV), Italy \\ ${ }^{4}$ National Park of Port-Cros, France \\ ${ }^{5}$ Oceanographic Museum of Monaco, Monaco \\ ${ }^{6}$ University of Annaba, Laboratoire of the Marine Bioressources, Annaba, Algeria \\ ${ }^{7}$ Oceanographic Institut Paul Ricard, Les Embiez, France \\ ${ }^{8} 11$ Rue Colomba, Ajaccio, France \\ 91 Allée Ermitage, Castelnau-le-Lez, France
}

Francour P., Cottalorda J.-M., Aubert M., Bava S., Colombey M., Gilles P., Kara H., Lelong P., Mangialajo L., Miniconi R. ${ }^{8}$, Quignard J.-P. 2010. Recent occurrences of opah, Lampris guttatus (Actinopterygii, Lampriformes, Lampridae), in the western Mediterranean Sea. Acta Ichthyol. Piscat. 40 (1): 91-98.

\begin{abstract}
The first records of Lampris guttatus in the Mediterranean Sea date back to 1807. Yet, until now it has been considered as a rare species (less than 25 specimens recorded in the literature). Since 2008, at least 23 specimens have been fished or observed along the French Mediterranean coast. In this paper, we present an updated review of records in the Mediterranean and discuss the possible link with the present sea water warming. We hypothesise that the recent Mediterranean specimens could come from the Atlantic, throughout the Gibraltar Strait, following a northward migration along the Northeast Atlantic coast due to present global warming.
\end{abstract}

Keywords: new records, first record, Algeria, Mediterranean, rare species, SST, warming

Among the Lampridiformes (7 families, 12 genera, 21 species), the Lampridae include a single genus (Lampris) and two living species worldwide: L. guttatus (Brünnich, 1788) and L. immaculatus Gilchrist, 1904, both exclusively marine (Wiley et al. 1998, Froese and Pauly 2008). Only L. guttatus, a bathypelagic, mid-water pelagic species, occurs in the Mediterranean between 100 and $400 \mathrm{~m}$ depth (Briggs 1960, Palmer 1986).

This uncommon species has a worldwide oceanic distribution in tropical to temperate waters (see Collette 2002, Froese and Pauly 2008) and belong to the bitemperatesubtropical pattern according to Krefft (1976). The first record and drawing of $L$. guttatus is a specimen caught at South Queensferry (Edinburgh, Scotland), and figured by Sir Robert Sibbald in 1664 in his Scotia Illustrata (Cuvier and Valenciennes 1835, D'Arcy Wentworth Thompson 1918). However, the first specimen to be described in detail was obtained by a certain Dr Mortimer, caught in the same area at Leith (the harbour of Edinburgh) in the year 1750 (Cuvier and Valenciennes 1835, D'Arcy Wentworth Thompson 1918). In his description, Dr Mortimer has added "that the Prince of Anamaboo, a country on the west coast of Africa, being then in England, recognised the fish immediately as a species common on that coast, which the natives called Opah, and said it was good to eat".

Lampris guttatus is also known in the Mediterranean (Tortonese 1963, Palmer 1986, Bauchot 1987, Quignard and Tomasini 2000), but as mentioned by Dulčić et al. (2005), in spite of his undoubted presence in the Mediterranean, published papers on its occurrence (date of capture, location), morphometrics, length and weight, food and feeding are very scarce (Table 1, Fig. 1). L. guttatus has been recorded in Italy by Spinola (1807; Ligurian Sea; it could be the first mention of this species in the Mediterranean Sea); Ariola (1904; Ligurian Sea),

\footnotetext{
* Correspondence: Prof. Patrice Francour, University of Nice-Sophia Antipolis. E.A. 4228 ECOMERS, Parc Valrose, 06108 Nice cedex 2. France, phone: +33(0)492076832, e-mail: francour@unice.fr.
} 
Tortonese (1970; Ligurian Sea), Andaloro and Di Natale (1979; southern Tyrrhenian Sea), and Psomadakis et al. (2006; central Tyrrhenian). Mercader et al. (2001) include this species in the ichthyofauna list of north-eastern Spain, but it has never been recorded in the Cabrera archipelago, Balearic Islands (Riera et al. 1993). However, in an earlier study, Gibert (1913) considers that L. guttatus was rare and new in Catalonia (north-eastern Spain), but abundant in Majorca (Balearic Islands, Spain). Five occurrences were reported for Croatia, in Adriatic (Katurić 1902, Crnković 1957). This species has also been found in Greece (Ondrias 1971), but the first documented record is from 2002 (Sinis 2004). In the Eastern Mediterranean, L. guttatus is absent from Israel (Golani 2005), but mentioned in Turkey (Bilecenoglu et al. 2002). However, these authors do not report direct observation along the Turkish coast, but they cite Palmer (1986) who considers that the eastward distribution of this species reaches as far as the Marmara Sea. Until now, there have been no reports of L. guttatus in the south-western
Mediterranean: Algeria (Dieuzeide et al. 1959, Djabali et al. 1993) and Tunisia (Bradai et al. 2004).

L. guttatus is considered to occur along the French Mediterranean coast of Provence, and few clear records have been published: Risso (1826), one specimen beached close to Nice (probably the first record of this species along the French Mediterranean coast); Cuvier and Valenciennes (1835) record one specimen fished in 1829 close to Toulon, and another one near Marseille in 1829 while Marion (1883) records 2 individuals in Marseille bay. In the latter record no details are being given and they could be the same individuals reported by Cuvier and Valenciennes (1835). However, Carus (1893) mentions that L. guttatus has been reported by Marion from Marseille (Ratonneau Island, 10-25 m depth) and Méjean (close to Marseille). All other publications refer probably to these first records and all considered L. guttatus as rare or very rare (e.g., De La Blanchère 1868, Moreau 1881, Regius 1882, Gourret 1894). After 1900, there is no new record until Francour (1999) who reported one specimen

Table 1

Bibliographic references of Lampris guttatus in the Mediterranean Sea and additional records from Algeria and Italy. RN: record number (letters denote sampling sites on the map-Fig. 1)

\begin{tabular}{|c|c|c|c|c|c|}
\hline $\begin{array}{l}\text { Date } \\
\text { [YYYY/MM/DD] }\end{array}$ & Reference & $(\mathrm{RN})$ Site & Length $[\mathrm{cm}]$ & Weight $[\mathrm{kg}]$ & Depth $[\mathrm{m}]$ \\
\hline before 1807 & Spinola (1807) & (a) Ligurian Sea & - & - & - \\
\hline before 1826 & Risso (1826) & (b) Nice & 50 & 5 & beach \\
\hline 1829 & $\begin{array}{l}\text { Cuvier and Valenciennes } \\
(1835)\end{array}$ & (c) Toulon & ca. 100 & - & - \\
\hline 1829 & $\begin{array}{l}\text { Cuvier and Valenciennes } \\
(1835)\end{array}$ & (d) Marseille & ca. 80 & - & - \\
\hline $1898 / 07 / 12$ & Ariola (1904) & (e) Viareggio (Italy) & 120 & - & - \\
\hline $1901 / 06 / 04$ & Ariola (1904) & (f) Camogli & 86 & 17 & - \\
\hline $1902 / 03 / 12$ & Katurić (1902) & $\begin{array}{l}\text { (g) Novigrad Sea } \\
\text { (Croatia) }\end{array}$ & 115 & 37 (a) & - \\
\hline $1902 / 03$ & Katurić (1902) & $\begin{array}{l}\text { (h) Novigrad Sea } \\
\text { (Croatia) }\end{array}$ & - & 27 & - \\
\hline $1956 / 10 / 09$ & Crnković (1957) & (i) Bakar Bay (Croatia) & 106 & 29 & - \\
\hline before 1970 & Tortonese (1970) & (j) Finale Ligure & 95 & 28 & - \\
\hline $1974 / 06 / 02$ & Cattaneo and Bava (2009) & (k) Camogli & ca. 60 & ca. 24 & - \\
\hline $1979 / 04 / 24$ & $\begin{array}{l}\text { Andaloro and Di Natale } \\
\text { (1979) }\end{array}$ & (1) Pizzo Calabro (Italy) & 96.0 & 39 (b) & 240 \\
\hline $1994 / 10 / 15$ & $\begin{array}{l}\text { Bartulović (pers. comm. } \\
\text { in Dulčić et al. 2005) }\end{array}$ & $\begin{array}{l}\text { (m) Neretva estuary } \\
\text { (Croatia) }\end{array}$ & - & 28 & 一 \\
\hline 1998/summer & Psomadakis et al. (2006) & (n) Anzio (Italy) & 110 & 33 & - \\
\hline 1999/summer & Psomadakis et al. (2006) & (o) Anzio (Italy) & 70 & 20 & - \\
\hline 1999/summer & Psomadakis et al. (2006) & (p) Anzio (Italy) & - & 11 & - \\
\hline $2001 / 06$ & Psomadakis et al. (2006) & (q) Anzio (Italy) & 60 & - & - \\
\hline $2002 / 09 / 26$ & Sinis (2004) & (r) Nea Skioni (Greece) & 86 & 20.52 & 370 \\
\hline $2003 / 07 / 13$ & Dulčić et al. (2005) & (s) Vir Island (Croatia) & 48.3 & 25.57 & 28 \\
\hline $2008 / 01 / 31$ & present paper & (t) Gouraya (Algeria) & 38.5 & 1.28 & 28 \\
\hline $2008 / 05 / 02$ & present paper (c) & (u) Camogli (Italy) & $70(\mathrm{FL})$ & 19.4 & $0-40$ \\
\hline $2008 / 05 / 04$ & present paper (c) & (v) Camogli (Italy) & - & 32 & $0-40$ \\
\hline $2008 / 05 / 07$ & present paper (c) & (w) Camogli (Italy) & - & 20 & $0-40$ \\
\hline $2009 / 04 / 29$ & present paper & (x) Camogli (Italy) & - & 30 & $0-40$ \\
\hline
\end{tabular}

$\mathrm{a}=$ without gill-rakers and digestive tract; $\mathrm{b}=$ eviscerated weight; $\mathrm{c}=$ these records have been firstly mentioned by CattaneoVietti and Bava (2009), without detail about date or size. 


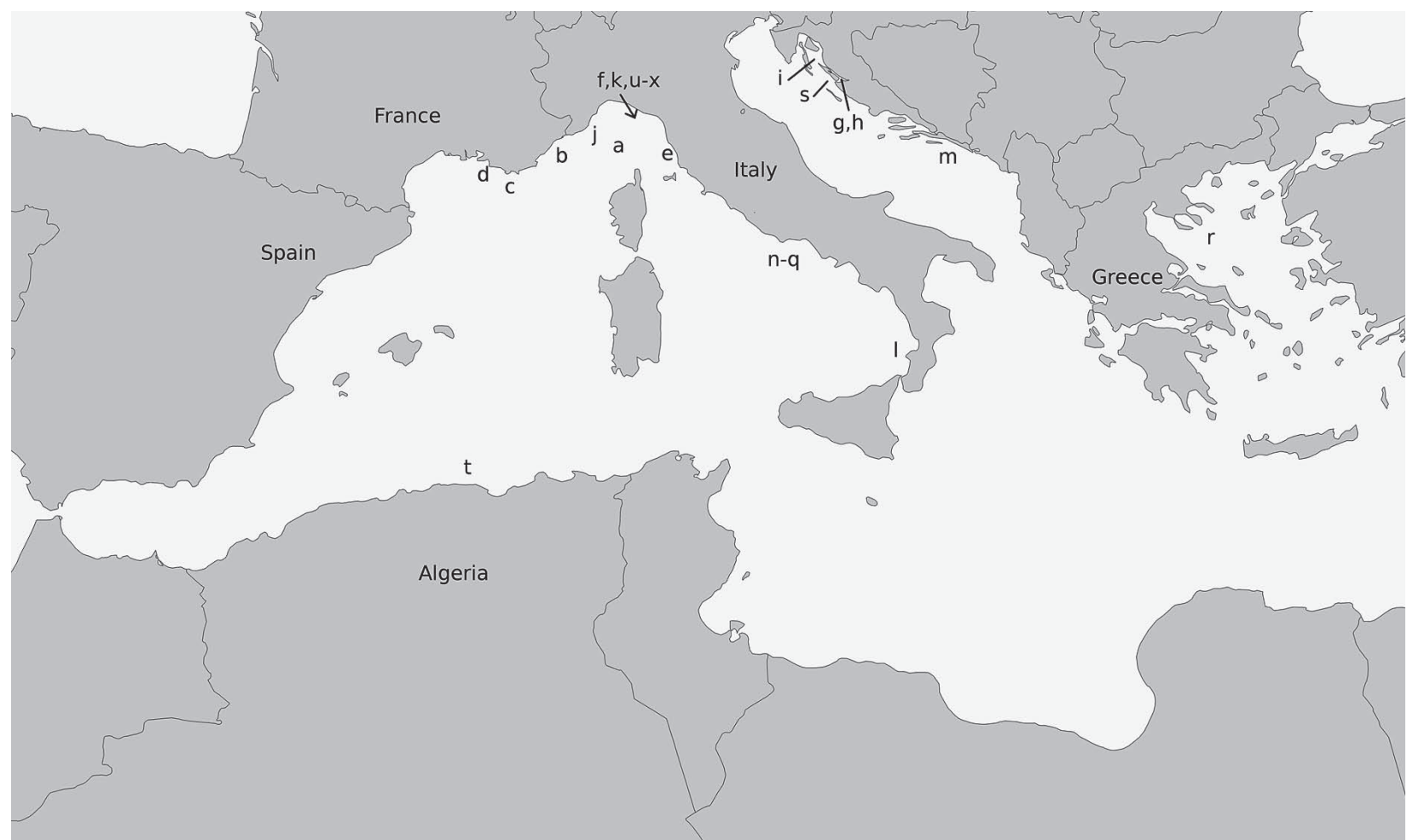

Fig. 1. Localisation of the published records of Lampris guttatus within the Mediterranean sea; Abbreviations explained in Table 1

captured near Les Embiez Island in 1997 (the same record is also reported in Quignard and Tomasini 2000). In this paper, we report recent occurrences of L. guttatus in the western Mediterranean, mainly along the French Mediterranean coast, and review all the available knowledge about its distribution and abundance.

During the last decade (from August 1997 to June 2008), at least 23 specimens of L. guttatus were observed or captured along the French Mediterranean coasts (Table 2, Fig. 2). Twelve of them came from the Var Department, and 7 from the Alpes-Maritimes department. Twelve of the 23 records were registered since 2008.

Only four individuals (record number $(\mathrm{RN}): 1,4,6$, and 13; Table 2) have been precisely sized. However, according to the information and/or the photographs given by the fishermen, scuba divers or scientists who reported these new occurrences, we estimated that the fish sizes ranged from 50 to $120 \mathrm{~cm}$ total length (TL). The measured weight ranged from $6 \mathrm{~kg}$ (ca. $55 \mathrm{~cm} \mathrm{TL}$ ) to $45 \mathrm{~kg}$ (more than $100 \mathrm{~cm}$ TL; Table 2).

Of these 23 specimens, nine were observed in shallow waters: swimming at the surface (RN: 10, 23), at 5-10 m depth (RN: 6, 20), in a harbour (RN: 11) or in a bay before to be stranded on the beach (specimens 5, 7, 17, and 22). Seven others (RN: 3, 9- the single one spear fished-12, $15,16,19$, and 21) were sampled at about 20-40 m depth. Finally, four L. guttatus were fished deeper, below $60 \mathrm{~m}$ depth (RN: 8, 13, 14, and 18).

In addition to these records along the French Mediterranean coast, we also report very recent records of L. guttatus from Algeria and Italy (Tab. 1). In Algeria, a single specimen has been fished by trammel net, offshore of Gouraya (west of Algiers, Algeria) in January 2008 , at $28 \mathrm{~m}$ depth. This small sized specimen from Algeria (38.5 cm TL; $1.281 \mathrm{~kg}$ ) has been deposited in the "Centre National de Recherche et de Développement de la Pêche et de l'Aquaculture" under the number CNRDPA $n^{\circ} 02 / \mathrm{fev} / 08$. In Italy (Ligurian Sea), 4 individuals have been fished in May 2008 and April 2009, close to the city of Camogli, by "tonnarella", a tuna trap, as a by-catch of tuna fisheries.

The main morphometric and meristic data of the specimen 13 from Cagnes-sur-Mer and Algeria (Table 3) fit with the previous descriptions of the species (see Dulčic et al. 2005, Froese and Pauly 2008).

No other large marine fish has this typical shape of body (deep-bodied, laterally compressed fish, long and red-coloured fins) that Smith (1950) described as "an unusual combination of size, beauty and good eating". Due to the conspicuous and distinctive colour pattern of this species, the specimens were identifiable without doubt, in situ or immediately upon discovery (on the beach or into a net) without any problems in their identification.

The recent record of L. guttatus along the Algerian coast seems to be the first documented one in the south-western Mediterranean. Along the French Mediterranean coast, few clear records of L. guttatus were available before 1997, and, thus, it was considered as a rare or very rare fish (e.g., Gourret 1894, De La Blanchère 1868, Moreau 1881, Marion 1883, Quignard and Tomasini 2000), although the flesh of this fish is consumable and highly esteemed (e.g., Tortonese 1970) and that species identification is easy. 
New records of Lampris guttatus along the French coast of Mediterranean Sea

\begin{tabular}{|c|c|c|c|c|c|c|c|c|c|}
\hline \multirow{2}{*}{$\begin{array}{l}\text { Record } \\
\text { No. }\end{array}$} & \multirow{2}{*}{$\begin{array}{c}\text { Date } \\
\text { [YY/MM/ } \\
\text { DD] }\end{array}$} & \multirow{2}{*}{ Site } & \multirow{2}{*}{ Department } & \multirow{2}{*}{$\begin{array}{l}\text { Sampling or } \\
\text { observation }\end{array}$} & \multicolumn{3}{|c|}{ Length $[\mathrm{cm}]$} & \multirow{2}{*}{$\begin{array}{l}\text { Weight } \\
{[\mathrm{kg}]}\end{array}$} & \multirow{2}{*}{ Depth [m] } \\
\hline & & & & & TL & FL & SL & & \\
\hline 1 & $97 / 08$ & $\begin{array}{l}\text { Toulon/ } \\
\text { Embiez }\end{array}$ & Var & - & 105 & 93 & 83 & - & - \\
\hline 2 & $97 / 08$ & Bandol & Var & professional fishing & - & - & - & ca. 50 & - \\
\hline 3 & $\begin{array}{c}98 \text { or } \\
00 / 04 \text { or } \\
05\end{array}$ & $\begin{array}{l}\text { Porquerolles } \\
\text { Island }\end{array}$ & Var & gillnet-trammel net & ca. 100 & - & - & ca. 40 & $\begin{array}{l}30 \text { (rock/ } \\
\text { seagrass) }\end{array}$ \\
\hline 4 & $00 / 05$ & Sète & Hérault & trammel net & 80 & 73 & 67 & - & - \\
\hline 5 & $03 / 03 / 24$ & Embiez & Var & Stranding & - & - & - & - & beach \\
\hline 6 & 04/01/06 & $\begin{array}{l}\text { Bormes-les- } \\
\text {-Mimosas }\end{array}$ & Var & live bait (Belone sp.) & 110 & - & - & ca. 50 & $\begin{array}{c}5-10 \text { (rock/ } \\
\text { seagrass) }\end{array}$ \\
\hline 7 & $04 / 04$ & $\begin{array}{l}\text { Bormes-les- } \\
\text {-Mimosas }\end{array}$ & Var & stranding (injured) & - & - & - & ca. 30 & beach \\
\hline 8 & $07 / 05$ & Antibes & $\begin{array}{c}\text { Alpes- } \\
\text {-Maritimes }\end{array}$ & fishing net & ca. 55 & - & - & 6 & 90 \\
\hline 9 & $07 / 07$ & North Bastia* & Corsica & spear fishing & - & - & - & $30-35$ & shallow water? \\
\hline 10 & $07 / 09 / 11$ & Embiez & Var & amateur sailors & - & - & - & - & surface \\
\hline 11 & $07 / 10 / 21$ & Marseille & $\begin{array}{l}\text { Bouches-du- } \\
\text {-Rhône }\end{array}$ & harbour (injured) & $\begin{array}{c}\text { ca. } \\
50-60\end{array}$ & - & - & - & surface \\
\hline 12 & $08 / 02 / 26$ & Giens & Var & gillnet-trammel net & - & - & - & 45 & $\begin{array}{l}30 \text { (rock/ } \\
\text { seagrass) }\end{array}$ \\
\hline 13 & $08 / 03 / 11$ & Antibes & $\begin{array}{c}\text { Alpes- } \\
\text {-Maritimes }\end{array}$ & fishing net & 118 & 101 & - & 32 & 200 \\
\hline 14 & $08 / 03 / 15$ & $\begin{array}{l}\text { off Le Levant } \\
\text { Island }\end{array}$ & Var & jig & ca. 100 & - & - & 40 & $60-120$ \\
\hline 15 & $08 / 03 / 17$ & off Nice & $\begin{array}{c}\text { Alpes- } \\
\text {-Maritimes }\end{array}$ & fishing net & ca. 100 & - & - & 42 & $30-40$ \\
\hline 16 & $08 / 04$ & off Nice & $\begin{array}{c}\text { Alpes- } \\
\text {-Maritimes }\end{array}$ & fishing net & ca. 70 & - & - & 27 & $30-40$ \\
\hline 17 & $08 / 04 / 30$ & $\begin{array}{l}\text { Porquerolles } \\
\text { Island }\end{array}$ & Var & stranding & ca. 100 & - & - & - & beach \\
\hline 18 & $08 / 05$ & $\begin{array}{c}\text { off Cagnes sur } \\
\text { Mer }\end{array}$ & $\begin{array}{c}\text { Alpes- } \\
\text {-Maritimes }\end{array}$ & fishing net & ca. 75 & - & - & $30-35$ & $100-150$ \\
\hline 19 & $08 / 06 / 13$ & Saint-Raphaël & Var & gillnet-trammel net & - & - & - & $25-30$ & $\begin{array}{l}\text { ca. } 30 \text { (rock/ } \\
\text { seagrass) }\end{array}$ \\
\hline 20 & 08/08 & $\begin{array}{l}\text { off Saint } \\
\text { Raphaël }\end{array}$ & Var & drift-net & - & - & - & 40 & ca. 10 \\
\hline 21 & $08 / 11 / 21$ & Antibes & $\begin{array}{c}\text { Alpes- } \\
\text {-Maritimes }\end{array}$ & fishing net & - & - & - & 35 & $\begin{array}{l}25-30 \text { (rock/ } \\
\text { seagrass) }\end{array}$ \\
\hline 22 & $09 / 02$ & East Corsica* & Corsica & stranding & - & - & - & $30-35$ & beach \\
\hline 23 & $09 / 04$ & Cannes & $\begin{array}{c}\text { Alpes- } \\
\text {-Maritimes }\end{array}$ & amateur sailors & ca. 100 & - & - & - & surface \\
\hline
\end{tabular}

* records first published in Miniconi (2009); TL = total length; $\mathrm{SL}=$ standard length; FL = fork length.

These 23 recent records since 1997 confirm unquestionably the presence of this species along the French Mediterranean coast. In addition, its presence seems recent and now L. guttatus could be considered as not infrequent due to the number of records during the last two years. In comparison,
Dulčić et al. (2005) reported only 5 specimens in Adriatic but for a longer period (1902 to 2003).

All the records analysed in this paper were structured in time and space. Among the 23 records, 19 specimens were recorded along a small part of the French 


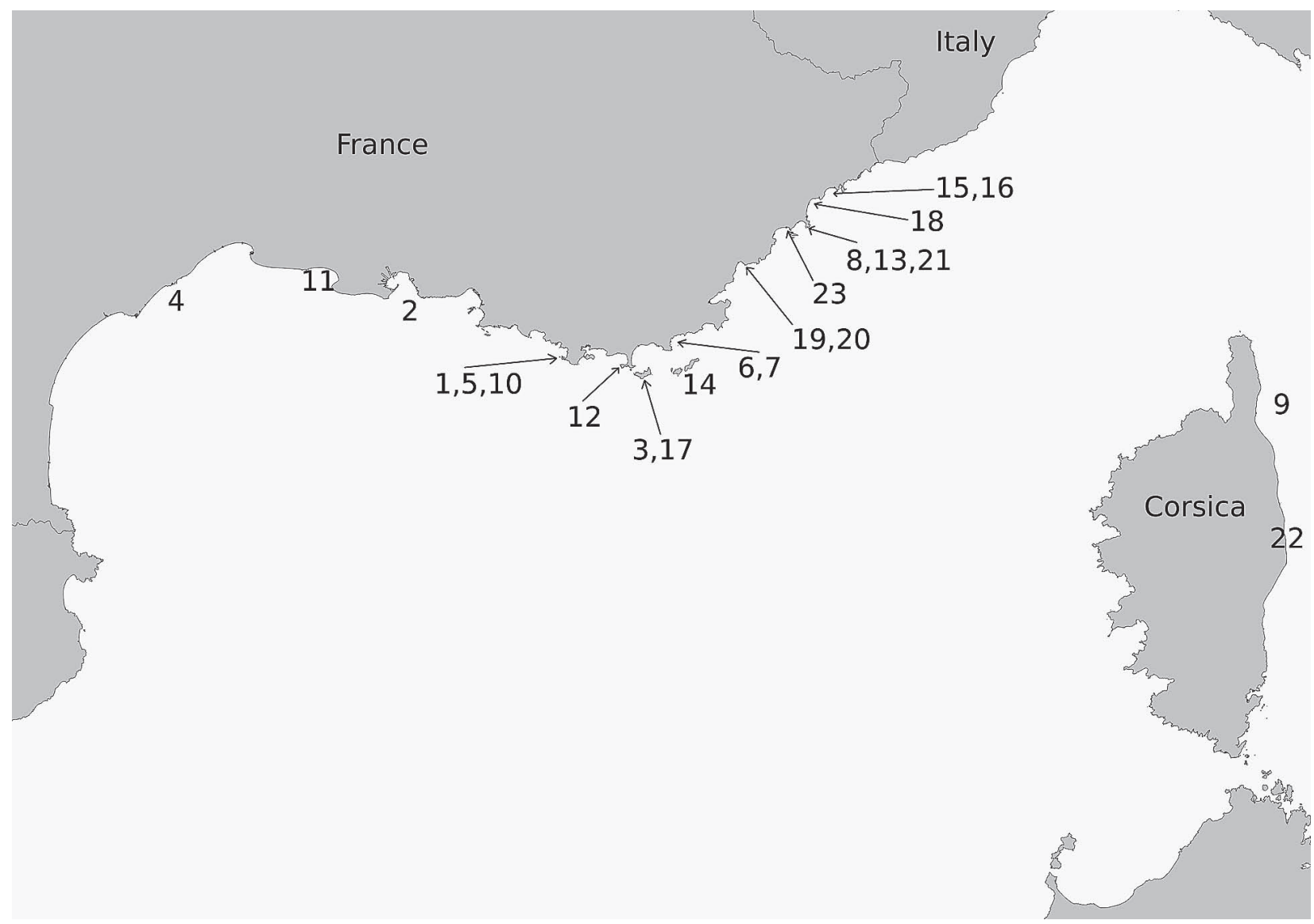

Fig. 2. Localisation of the new records of Lampris guttatus along the French Mediterranean coast; the numbers denote records described in Table 2

Mediterranean coast, mainly eastward, close to the Ligurian Sea where the past couple of years this species is more frequently observed (Cattaneo-Vietti and Bava 2009, present paper). Approximately one half (12 on 23) of the specimens were recorded after 2008. Moreover, most of the records (15 on 23) were from April to October. Similarly, Risso (1826) mentions records in autumn. Dulčić et al. (2005) reported captures in Adriatic from March to October. In Italy, Ariola (1904) records the presence of the species in June, Psomadakis et al. (2006) in summer, and Andaloro and Di Natale (1979) in April. In Greece, Sinis (2004) reported the first record of L. guttatus in September 2002. Additionally, 23 specimens of L. guttatus were observed or captured alone, as reported by Dulčić et al. (2005). That confirms the comment of Palmer (1986) who considered L. guttatus as a rather solitary fish.

Many new species have been recorded for the first time because they were brought to scientists by fishermen (see Ben Rais Lasram and Mouillot 2009). Yet, there is no reason to believe that the fishing effort is more intense now that it was 10-20 years ago or previously. In addition, in Camogli, the "tonnarella" net operate in the area in the traditional way since at least two or three centuries, and no clear previous record of opah has been reported. Thus, the recent records in France, Croatia, Italy, and Algeria correspond to a true increase of its abundance in the Western Mediterranean and the Adriatic. So, how to explain the clear increase of occurrence in the last years and such a geographic distribution?

Polovina et al. (2008) recently suggested that opah in the Central North Pacific may be adjusting their vertical behaviour to maintain a constant mean daily temperature over a 24-hour period. When moving through changing local conditions, they tend to adjust their depth according to this physiological constraint. This indicates that opah cannot thermoregulate itself like some species of tuna (Polovina et al. 2008). The same authors showed that opahs are found in waters whose the mean daily temperature is limited to a narrow range from about 14.7 to $16.5^{\circ} \mathrm{C}$, i.e., between 150 and $200 \mathrm{~m}$ depth. However, during the night, opahs migrate to shallower waters (about 50 $\mathrm{m}$ depth) with higher temperature. This particular behaviour corresponds to the thermoregulation behaviour described by Golovanov (2006). The depth of capture is known for 19 of the 23 records: nine opahs have been observed close to the surface or stranded on a beach, six between 20 and $40 \mathrm{~m}$ depth, and four have been caught deeper, between 60 and $200 \mathrm{~m}$ depth. Therefore, we can hypothesise that (i) the stranding on the beaches occurred during the night or concerned only not healthy individuals, (ii) the observations close to the surface could concern not healthy or injured specimens unable to reach deepest waters after a night migration upward the surface, and (iii) the presence of L. guttatus below 20/30 m depth is consis- 
Table 3

Morphometric and meristic data of the specimen No. 13 from Cagnes-sur-Mer, France (see Table 2) and from Gouraya, Algeria (see Table 1)

\begin{tabular}{lcc} 
Character & $\begin{array}{c}\text { Specimen } 13 \text { from } \\
\text { Cagnes-sur-Mer }\end{array}$ & Specimen from Gouraya \\
\hline Total length & 118 & 38.5 \\
Fork length & 101 & 33.5 \\
Maximal body depth & 52 & 20.0 \\
Preorbital length & 12 & 2.7 \\
Postorbital length & 30 & 4.5 \\
Peduncle height & 7 & 2.3 \\
Eye diameter & 4.5 & 2.5 \\
Eye to pectoral length & 16 & 5.0 \\
Dorsal fin length & $22($ broken $)$ & 30.0 \\
Pectoral fin length & 24 & 9.0 \\
Ventral fin length & $22.5($ broken $)$ & 18.3 \\
Anal fin length & 30 & 12.5 \\
Ventral to anal fin length & 12 & 4.2 \\
Caudal fin height & 32 & 12.5 \\
Dorsal fin rays & 50 & 54.0 \\
Pectoral fin rays & 25 & 15.0 \\
Anal fin rays & 40 & 36.0 \\
\hline
\end{tabular}

tent with their optimal temperature (Golovanov 2006, Polovina et al. 2008).

Polovina et al. (2008) described vertical migration to thermoregulate. Runcie et al. (2009) consider that the cranial endothermy exhibited by L. guttatus allows repeated dives into cool water. However, Krefft (1976) consider that some mid-water fish species growing to a comparatively large size, as L. guttatus, have far ranging feeding migration during the summer months to higher latitudes. Similarly, Tortonese (1970) described L. guttatus as living in warm water but migrating northward during the summer months. However, about one third of the specimens ( 8 on 23) have been recorded in winter, from November to March. Ben Rais Lasram et al. (2008) defined the mean latitude of a given fish species as the difference between the maximum and the minimum latitudes, i.e., the northernmost and southernmost edges of a species geographic range. Ben Rais Lasram and Mouillot (2009) showed a decrease in mean latitude for fishes that invade from the Atlantic. They also suggested that the currently warmer Mediterranean Sea (Somot et al. 2006) is acting increasingly as a catchment basin for southern species. Additionally, the species whose mean depth is less than $320 \mathrm{~m}$, such as L. guttatus, seem favoured during their spreading process contrary to deeper sea species (mean depth about $400 \mathrm{~m}$ or more) (Ben Rais Lasram et al. 2008).

Lampris guttatus has a worldwide distribution but has always been rare in the western Mediterranean and Adriatic. Since 2008 is more abundant along the French
Mediterranean coast and in the Ligurian Sea. This recent increase of records may be related to the present sea temperature increase in the north-western Mediterranean (Somot et al. 2006). This warming leads to changes of fauna and flora, with records of new thermophilic species spreading from the south-western Mediterranean (e.g., Francour et al. 1994, Bianchi 2007) or from the warmer part of the Atlantic through the Gibraltar Strait (Francour and Mouine 2008). The current records of opah in the Mediterranean could then be related to a previous entrance via the Gibraltar Strait. Such a modification linked to a northward spreading of opah in the Atlantic, increases the number of potential individuals spreading inside the Mediterranean. However, it is amazing that there is no record from the Mediterranean north-African coast, except for the single record we report in this paper, and from the warmer Eastern Mediterranean. Ben Rais Lasram et al. (2008) showed that the majority of neocoloniser fishes in the Mediterranean colonize only the northern side. According to the general circulation in the Mediterranean, with an Atlantic surface water inflow along the southern side, they logically expected a better colonization of the southern side than the northern one. They hypothesise that (i) a difference of primary production could involve such an asymmetry, or (ii) more exploration and more fish occurrence records on the northern side could be due to the larger human populations and consequently larger scientific communities. The new record of a probably very young specimen from Algeria 
(the smallest record in Mediterranean) could be linked to the spreading of young fishes northward in the Atlantic (the lower mean latitude highlighted by Ben Rais Lasram and Mouillot 2009) and the subsequent entrance into the Mediterranean.

The development of volunteer network in the Mediterranean as in coral reefs (e.g., see http://www.cybelle-planete.org) and a better cooperation with the professional fishermen will probably allow in the future to report previously unrecorded species and to monitor changing fauna and flora in the Mediterranean sea, and mainly in the southern side of the basin.

\section{ACKNOWLEDGEMENTS}

Special thanks to Jean Attard, François Cabane, Frédéric Cancian, Gérard Carodano, Jean-Philippe Catteau and Stéphane Jamme, Eric Charbonnel, Philippe Chateau, Daniel Cozzolino, Christian Decugis, Henri Dupuis, Flavien Falchetto, Alain Ferrero, Thierry Génovèse, François Giordanengo, Laurent Markovic, Henri Mennella, Philippe Michat, Georges Raynaut, Alain Riva, Jean-Marie and Sauveur Roméo, Antoine Saissy, Tanja Stojanov, and Marc Verlaque.

\section{REFERENCES}

Andaloro F., Di Natale A. 1979. Ritrovamento di un esemplare di Lampris guttatus (Brünnish, 1788) (Pisces, Lampridae) nelle acque del basso Tirreno. [The finding of a single specimen of Lampris guttatus (Brünnish, 1788) (Pisces, Lampridae) in the waters of the lower Tyrrhenian.] Memorie di biologia marina e di oceanografia 9 (4): 111-113. [In Italian.]

Ariola V. 1904. Pesci nuovi o rari per il golfo di Genova. [New or rare fishes of the Golf of Genoa.] Annali del Museo Civico di Storia Naturale di Genova 3 (1): 153-168. [In Italian.]

Bauchot M.L. 1987. Poissons osseux. Pp. 891-1421. In: Fisher W., Bauchot M.L., Schneider M. (eds.) Fiches FAO d'identification pour les Besoins de la Pêche (rev. 1). Méditerranée et Mer Noire. Zone de Pêche 37. Vol. II. FAO, Rome.

Ben Rais Lasram F., Mouillot D. 2009. Increasing southern invasion enhances congruence between endemic and exotic Mediterranean fish fauna. Biological Invasions 11 (3): 697-711. DOI: 10.1007/s10530-008-9284-4.

Ben Rais Lasram F., Tomasini J.A., Romdhane M.S., Do Chi T., Mouillot D. 2008. Historical colonization of the Mediterranean Sea by Atlantic fishes: do biological traits matter? Hydrobiologia 607 (1): 51-62. DOI: $10.1007 / \mathrm{s} 10750-008-9366-4$.

Bianchi C.N. 2007. Biodiversity issues for the forthcoming tropical Mediterranean Sea. Hydrobiologia 580 (1): 7-21. DOI: 10.1007/s10750-006-0469-5.

Bilecenoglu M., Taskavak E., Mater S., Kaya M. 2002. Checklist of the marine fishes of Turkey. Zootaxa 113: 1-194.

Bradai M.N., Quignard J.-P., Bouain A., Jarboui O., OuannesGhorbel A., Ben Abdallah L., Zaouali J., Ben Salem S. 2004. Ichtyofaune autochtone et exotique des côtes tunisiennes: recensement et biogéographie. Cybium 28 (2): 315-328.

Briggs J.C. 1960. Fishes of worldwide (circumtropical) distribution. Copeia 1960 (3): 171-180.
Carus J.V. 1893. Prodromus faunae Mediterraneae. Vol. 2. E. Schweizerbart'sche Verlagshandlung (E. Kock) Stuttgart.

Cattaneo-Vietti R., Bava S. 2009. La tonnarella e la pesca tradizionale a Camogli. [The tonnarella and the traditional fishing in Camogli.] Le Mani, Recco. [In Italian.]

Collette B.B. 2002. Lampridae. Opahs. P. 952. In: Carpenter K.E. (ed.) FAO species identification guide for fishery purposes. The living marine resources of the western central Atlantic. Vol. 2. Bony fishes. Part 1 (Acipenseridae to Grammatidae). FAO, Rome.

Crnković D. 1957. Tunere i njihove neobične lovine. [Tunafishing stations and their unusual catches.] Morsko Ribarstvo 1: 23-24. [In Croatian.]

Cuvier G., Valenciennes A. 1835. Histoire naturelle des poissons. Tome X. Levrault, Paris.

D'Arcy Wentworth Thompson C.B. 1918. The scarcer fishes of the Aberdeen market (part II). The Scottish Naturalist 74 (2): 35-46.

De La Blanchère H. 1868. Nouveau dictionnaire général des pêches. Réimpression Bibliothèque des introuvables, Paris 2001.

Dieuzeide R., Novella M., Roland J. 1959. Catalogue des poissons des côtes algériennes. Tome II ( $2^{\circ}$ édition). Imbert, Alger.

Djabali F., Brahmi B., Mammasse M. 1993. Poissons des côtes algériennes. Pelagos, (Bulletin de l'Institut des Sciences de la Mer et de l'Aménagement du Littoral) ( ${ }^{\circ}$ special): 1-215.

Dulčić J., Jardas I., Pallaoro A. 2005. New record of opah Lampris guttatus (Lampridae) in the Adriatic waters with a review of Adriatic records. Cybium 29 (2): 195-197.

Francour P. 1999. Le Lampris, la Méditerranée et le réchauffement. Océanorama 30: 19-23.

Francour P., Boudouresque C.F., Harmelin J.G., HarmelinVivien M., Quignard J.P. 1994. Are the Mediterranean waters becoming warmer? Information from biological indicators. Marine Pollution Bulletin 28 (9): 523-526. DOI: 0025-326X(94)0068-9.

Francour P., Mouine N. 2008. First record of Kyphosus sectator (Kyphosidae) along the French Mediterranean coast. Cybium 32 (3): 275-276.

Froese R., Pauly D. (eds.) 2008. FishBase. [version 04/2008] http://www.fishbase.org.

Gibert A.M. 1913. Fauna ictiologica de Catalunya. Laborde, Barcelona.

Golani D. 2005. Checklist of the Mediterranean fishes of Israel. Zootaxa 947: 1-90.

Golovanov V.K. 2006. The ecological and evolutionary aspects of thermoregulation behavior on fish. Journal of Ichthyology 46 (suppl. 2): S180-S187. DOI: 10.1134/S0032945206110075.

Gourret P. 1894. Provence des pêcheurs. [Réimpression de 1981.] Serre, Nice.

Katurić M. 1902. Lampris luna Lin. 6. Rad jugoslavenske akademije znanosti i umjetnosti 149: 89-92.

Krefft G. 1976. Distribution patterns of oceanic fishes in the Atlantic Ocean. Revue des Travaux de l'Institut des Pêches maritimes 40 (3/4): 439-460.

Marion M.A.F. 1883. Esquisse d'une topographie zoologique du golfe de Marseille. Annales du Musée d'Histoire naturelle de Marseille 1: 1-108. 
Mercader L., Lloris D., Rucabado J. 2001. Tots els peixos del Mar Català. Diagnosis i claus d'identificacio. Institut d'Estudis Catalans, Barcelona.

Miniconi R. 2009. Inventaire des poisons de Corse (2e complement). Stantari 17: 65-68.

Moreau E. 1881. Histoire naturelle des poisons de la France. Vol. 2. G. Masson, Paris.

Ondrias J.C. 1971. A list of the fresh and sea water fishes of Greece. Praktica of the Institute of Oceanographic and Fishing Research, Period C, 10a: 23-96.

Palmer G. 1986. Lamprididae. Pp. 725-726. In: Whitehead P.J.P., Bauchot M.-L., Hureau J.-C., Nielsen J., Tortonese E. (eds.) Fishes of the north-eastern Atlantic and the Mediterranean. Vol. 2. UNESCO, Paris.

Polovina J.J., Hawn D., Abecassis M. 2008. Vertical movement and habitat of opah (Lampris guttatus) in the central North Pacific recorded with pop-up archival tags. Marine Biology 153 (3): 257-267. DOI: 10.1007/s00227-007-0801-2.

Psomadakis P.N., Scacco U., Vacchi M. 2006. Recent findings of some uncommon fishes from the central Tyrrhenian Sea. Cybium 30 (4): 297-304.

Quignard J.P., Tomasini J.A. 2000. Mediterranean fish biodiversity. Biologia Marina Mediterranea 7 (3): 1-66.

Regius J.M.F. 1882. Essai sur 1'histoire naturelle des vertébrés de la Provence et des départements circonvoisins. Marius Lebon, Marseille.

Riera F., Pou S., Grau A.M. 1993. La ictiofauna. Pp. 623-644. In: Ballesteros E., Fornos J. (eds.) Historia natural de l'arxipèlag de Cabrera. CSCI, Palma de Mallorca.

Risso A. 1826. Histoire naturelle des principales productions de l'Europe méridionale et particulièrement celles des environs de Nice et des Alpes Maritimes. Tome III. Levrault, Paris.

Runcie R.M., Dewar H., Hawn D.R., Franck L.R., Dickson K.A. 2009. Evidence for cranial endothermy in the opah (Lampris guttatus). Journal of Experimental Biology 212 (4): 461-470. DOI: $10.1242 /$ jeb.022814.
Sinis A.I. 2004. First documented record of Lampris guttatus (Brünnich, 1788) opah, in Greek seas. Journal of Biological Research 2: 101-104.

Smith J.L.B. 1950. The sea fishes of southern Africa. Central News Agency, Cape Town, South Africa.

Somot S., Sevault F., Déqué M. 2006. Transient climate change scenario simulation of the Mediterranean Sea of the twenty-first century using a high-resolution ocean circulation model. Climate Dynamics 27 (7-8): 851-879. DOI: 10.1007/s00382-006-0167-z.

Spinola M. 1807. Sur quelques poissons peu connus du Golfe de Gênes. Annales du Muséum d'Histoire Naturelle 10: 366-380.

Tortonese E. 1963. Elenco riveduto dei Leptocardi, Ciclostomi, Pesci cartilaginei e ossei del mare Mediterraneo. [Revised list of leptocardians, cyclostomes, and cartilaginous and bony fishes of the Mediterranean Sea.] Annali del Museo Civico di Storia Naturale di Genova 74: 156-185. [In Italian.]

Tortonese E. 1970. Fauna d'Italia. Osteichthyes (Pesci Ossei). [The fauna of Italia. Osteichthyes (bony fishes).] Parte Prima. Edizioni Calderini, Bologna. [In Italian.]

Wiley E.O., Johnson G.D., Dimmick W.W. 1998. The phylogenetic relationship of lampridiform fishes (Teleostei: Acanthomorpha), based on a total-evidence analysis of morphological and molecular data. Molecular Phylogenetics and Evolution 10 (3): 417-425. DOI: 10.1006/mpev.1998.0532.

Received: 2 June 2009

Accepted: 14 December 2009 Published electronically: 25 June 2010 